\title{
Industry work experience and inventive capacity of South African academic researchers
}

\author{
Louis Mitondo Lubango ${ }^{\mathrm{a}}$, and Anastassios Pouris ${ }^{\mathrm{a}}$ \\ ${ }^{a}$ Institute for Technological Innovation, University of Pretoria, Pretoria 002, South \\ Africa
}

\section{Abstract}

The inventive capacity of South African universities and researchers is investigated through analysis of university patent applications. Patent applications to the South African Patent office from 1996 to 2006 are used as an indicator of inventive capacity. The investigation determines, for the first time, patenting activities of local universities at the South African Patent Office for the past 10 years and it identifies the performance of faculties and departments. We suggest that patent analysis of local patent offices in developing countries provides a more comprehensive picture of inventive activity than the analyses in the main patent offices in USA and Europe.

The assertion that industrial experience affects the inventiveness of academic staff is also investigated. The study finds that most inventors or co-inventors held at least one position in industry, or in some cases, specialized parastatals (non-university institutions) prior to patent application. The study supports the idea that experience and the professional trajectory of scientists through migration from industry to university leads to an increase of researchers' scientific and technical human capital which is convertible into high performance or inventive capacity. We argue that this linkage is valid equally in developed and developing countries (like South Africa) and that universities internationally wishing to improve their entrepreneurial character should aim to employ academic with industrial prior experience. 


\section{Article Outline}

1. Introduction

1.1. The South African patent system

2. Research methodology

3. Results and discussion

3.1. South African universities' inventive activity profile

4. Conclusion and recommendations

Acknowledgements

References

Vitae

\section{Introduction}

Access to knowledge and technology is recognized as one of the key steps towards the economic growth and well being of all nations. Many developing and developed countries strengthen their technological capacities as this can yield rapid increases in the productivity of both the capital and labor employed in the developmental process. Technological capacity is viewed here as the knowledge of "the technologies available; the ability to evaluate and select such technologies, to utilize, adapt, re-create and finally to further develop them” (Cummings and Teng, 2003; Madanmohan et al., 2004). This is prerequisite for independent technological developments and also for successful technology transfer. (Daghfous, 2004; Madanmohan et al., 2004).

Universities, in general, are currently undergoing a second revolution, incorporating economic and social development as part of their mission. The first academic revolution made research an academic function in addition to teaching. Today, the emerging entrepreneurial university integrates economic development as an additional function (Etzkowitz, 1998). Most universities actively engage in the process of technology transfer to generate wealth in addition to their first mission of teaching and generating public knowledge. Technology transfer is, according to Rogers et al. (2001), "the application of information into use"; and usually involves moving a technological innovation from an 
$\mathrm{R} \& \mathrm{D}$ organization to a receptor organization (e.g. private company). The process spans the stages from $R \& D$ to commercialization and beyond, but with a particular focus on the interface between R\&D (often by university research centre, a corporate unit, or by a government laboratory) and commercialization (often carried out by private company) (Rogers et al., 2001).

The common mechanisms through which technology transfer between university and industry occurs are: (i) spin off companies, (ii) licensing, (iii) publication, (iv) meetings, cooperative R\&D agreements, (v) joint research venture, personnel training, (vi) supervision of post-graduate students, etc.

Rogers et al. (2001) propose a composite measure of technology transfer effectiveness for US research universities based on six steps. The measures equally weight six indicators of technology transfer effectiveness: (i) the number of invention disclosures, (ii) the number of US patent applications filed, (iii) the number of technology licenses and options executed, (iv) the number of technology licenses and options yielding income, (v) the number of start-up companies spun off the university and (vi) the total amount of technology licensing royalties earned per year. Most works on technology transfer involving university (e.g., Hameri, 1996; Bray and Lee, 2000; Liu and Jiang, 2001; Chapple et al., 2005) highlight the complexity of the process involving highly complex, recursive and dynamic activities combined with a range of diverse and often conflicting stockholders.

Both the growing social pressure which are demanding useful research and the shrinking of academic research budgets that are motivating increase in focus on exploitable research are also influencing public R\&D institutes to forge the partnership with the industry to facilitate technology transfer. Important benefits expected from this partnership are: (i) exchange of technological information and sharing of R\&D cost and risks, (ii) learning vehicle to accumulate new skills and broaden the effective scope of activities and reduce technological uncertainty, (iii) gain access to financing, partner's R\&D facilities, expertise and new innovative technologies, (iv) networking to keep 
abreast of research get clash of views and cross-fertilization of ideas (Mohan and Rao, 2005; Veugelers and Cassiman, 2005).

The quest for best practices in the interaction between academia, industry and government that leads to a significant increase in inventive and innovative capacities is of obvious importance for policy of both public and private sectors as well as for institutional and portfolio evaluation.

Patents are documents providing legal protection of inventions and are the outcome of a complex process involving a dedication of a large volume of resources, including intellectual, technical etc; by research institutions to carry innovative activities (Nieto and Quevedo, 2005). Patents are a key step in the whole technological innovation process (Ndonzuau et al., 2002), and are usually used as indicator of inventive and innovative activities (Archibugi and Coco, 2005; Motohashi, 2005; Pouris, 2005; Miyata, 2000). Patent and patent applications can also be used to investigate technological change and the relationship between technological development and economic growth (Abraham and Moitra, 2001; Coombs et al., 1996; Gans and Hayes, 2005; Grupp and Mogee, 2004; Pouris, 2006). A number of studies use patents and patent applications to assess the level of technological development in a particular sector, and the interdependence between industrial sectors and technology (Abraham and Moitra, 2001).

The objective of the present study is two-fold: (i) to identify the patterns of patent activities in South African universities, (ii) to identify the influence of business work experience in academic inventive capacity. This is the first time South African universities' patenting activity in the South African Patent Office is investigated. Our study considers patenting activities at national level in contrast to studies which use patenting in a foreign patent office (USPTO, EPO, JPO). Watanabe et al. (2001), for example, show that Japan does not apply the same volume of applications to the USPTO as to the Japan Patent Office (JPO) due to costs constraints and market strategy. It can reasonably be argued that the same phenomenon appears in other countries. Patent applications at national level can give an extensive picture of the national innovative 
activities which is not provided by investigations of patenting activities in foreign countries.

Similarly we investigate the effects of prior working experience of academics in the private sector. Whereas the literature focuses mostly on various forms of partnership between institutions, including strategic alliances, network, joint research ventures etc are pursued for this end (Autio et al., 1996; Verspagen and Duysters, 2004; Numprasertchai and Igel, 2005), there seems to be a void on a systematic investigations on the effects of the prior working experience of researchers moving from private sectors to university on the production of university research centres in general and in developing countries in particular. The present study seeks fill this void.

A research similar to ours conducted by Dietz and Bozeman (Dietz and Bozeman, 2005) found a correlation between academic researchers patent and publication productivity and their previous work experience in industry and government. The authors argued that the effect of industry work experience is to increase both the social networks and scientific and technical human capital of researchers. Scientific and technical human capital are viewed as a unique synthesis of scientific, technical and social knowledge, with skills and resources embodied in a particular individual (Bozeman and Corley, 2004; Bozeman and Mangematin, 2004; Murray, 2004). This embedded knowledge is the combinations of individual's stores of tacit knowledge and have both cognitive and socially constructed elements (McAdam, 2004). Efforts to leverage this form of knowledge are of paramount importance for both industry and academia's researchers.

We assume that if technical capital is thus embodied in researchers working in industry as both Zellner (2003) and Faulkner (1998) argue, migrating from industry to university would obviously increase the foregoing capacity, needed on an institutional level in invention process by the university. This can reasonably be considered as a mechanism of knowledge and/or technology transfer from industry to university. We investigate whether researcher's career path, from industry and other non-university sectors to 
university can significantly boost scientific and technical human capital and university researcher's inventive capacity.

Provided that our investigation for South Africa will have similar findings as in the technological advanced countries, we could argue that the effect of industry work experience on academics - improved inventiveness—is a universal phenomenon and that universities internationally could use the finding as a policy instrument.

Next we describe the workings of the South African patent system; we outline the methodology used to gather data, and we discuss the findings.

\subsection{The South African patent system}

The South African patent system is managed by CIPRO (Company and Intellectual Property Registration Office) located in Pretoria, South Africa. In terms of the South African Pact Act (1978), a patent application may be filed by inventors, applicants or through the assistance of an expert in the patent matter (e.g. an attorney). South Africa is one of the 124 countries that accept the Patent Cooperation Treaty (PCT), allowing individuals to file an application at both local and international level in parallel. The international designates the countries in which applications are feasible. CIPRO follows section 25 of the South African Patent Act (Act 57) of 1978, defining patentable inventions to be: (i) those which involve inventive steps, and which are applicable to trade, industry or agriculture (ii) anything consisting of: (1) discovery, (2) scientific theory, (3) mathematical method, (4) scheme, rule or method for performing a mental act or of doing business, (5) a program for a computer.

The registration involves the following steps: (i) Search of existing patents. This step is not essential but is advisable to avoid infringing existing patents. It can be conducted by the inventor or the applicant. (ii) Application to Register. Any of the following methods can be applied: (1) Filing a provisional patent application. The cost in Rands (R) is R 60 and the process can be undertaken by the inventor, the applicant or with the assistance of an attorney or other expert. (2) Filing a complete application. (For ease of comparison 1 US Dollar is approximately equal to 7 Rands.) The cost is R 266 and this step must be 
undertaken with the assistance of an expert (attorney). (3) File a PCT. The process is considered when necessary. (iii) Registration. After a provisional patent application has been filed, the office of patent opens a file and provides a provisional application number. After 12 months the complete application can then be submitted.

When the application has been lodged, a formal examination usually lasting 6 months takes place. If successful, the application is accepted and the applicant is then required to publish his/her patent in the government owned Patent Journal. If within a three month period no objections have been made by the public, a Patent Certificate is issued. The lifespan of a patent can last 20 years, provided that it is renewed annually before the third year.

Hardcopies of patent applications and some patents granted are compiled in registers which are accessible to public. Registers are in many volumes and are arranged chronologically in a CIPRO's library. Indexes and cards are available in the library and can facilitate the search of patent applications, grants, and other intellectual property information. An electronic database of intellectual property, like patents, copyright, etc. is in the development phase and does not cover all the information available. Core information on patent application file appears in the following order: application number (and date), type of application (complete or provisional), title of application, name(s) of applicant(s), name(s) of inventor(s), country of priority, priority number, and priority date.

\section{Research methodology}

Five universities, with intense patent activities, including Stellenbosch University (SUN), University of Pretoria (UP), University of Cape Town (UCT), University of the North West (UNNW), and University of Witwatersrand Johannesburg (WITS) were investigated. Patent applications were collected from 1996 to 2006. Only patents owned by universities were considered. Patents owned by researchers (especially where researchers were applicants and owners) were not included. Hard copies of application files have been obtained from the Patent file Database, at CIPRO in Pretoria. The patent 
application indexes, cards and registration book were also used for verification of accuracy. Applications were counted manually and covered the whole year, i.e. from January to December. For the year 2006, the count went up to July. Details about application dates, names and addresses of inventor and co-inventor(s), applicants and assignees were obtained from the application files. For each claim, only the provisional application was used to avoid double or multiple counts. Complete application was only used when the provisional was not available. Additional details of applicants, faculties and inventors were obtained from university and faculty web sites. Amongst the inventors were also students, post-doctoral fellows and lecturers. Curriculum vitae of inventors were obtained from various sources including faculty or department web pages, professional association membership databases, journal articles (brief cvs), telephone calls and e-mail to inventor(s), etc. From five universities 245 patent applications were collected; 186 cvs of corresponding inventors (mainly professors and in some cases lecturers) were obtained and analyzed.

The control group has been created to test the importance of previous industry work experience on the determination of inventive capacity of university researchers. The control group consisted of 30 professors from the same departments (including Botany, Electrical, Electronic and Computer Engineering, Chemical Engineering, Mechanical Engineering, Microbiology, Biochemistry, Civil Engineering, Metallurgical Engineering and Veterinary Science) and from the institutions studied, i.e. SUN, WITS, UP, UNNW and UCT. A matching sampling approach was followed. None of the professors of the control group belonged to the initial population of inventors of the 245 patent applications investigated in this study. Names of these professors were obtained from the home pages of their departments and as necessary, they were asked by e-mails and/or telephone calls to provide their cvs. All members of this group were professors, mainly male, and aged between 35 and 60 years. Members of this group had the same background characteristics, belonging to a same institution; same departments and face the same labor market conditions that can affect performance. Analysis of the cvs identified two sub-groups. The first sub-group was made of 10 professors who all had previous industry work experiences. Seven of them had patent applications before the 
period in which patent applications are investigated in the present study, i.e. before 1996, and the remaining three professors had no applications. The second sub-group included 20 professors who had no previous industry work experience. None of them had a patent application.

The selection approach clearly made the two sub-groups of the control group significantly homogeneous and thus suitable for the comparison of their inventiveness based on the sole effect of previous industry working experience. In other words the threats to validity of comparison of the two sub-groups were significantly minimized. Considerable weight was thus given to the sole criteria of comparison, and the previous industry working experience, and the latter was zero in the second sub-group of control group, made of 20 professors. Due to the large magnitude of the difference in inventiveness of the two sub-groups of the control group, it appeared unnecessary to validate such difference through other statistical tests.

\section{Results and discussion}

\subsection{South African universities' inventive activity profile}

Fig. 1 shows the trend in inventive activity, as measured by patent applications, of five South African universities - the most active in patent activities (i.e. those having more than 16 patents over the past 10 years).

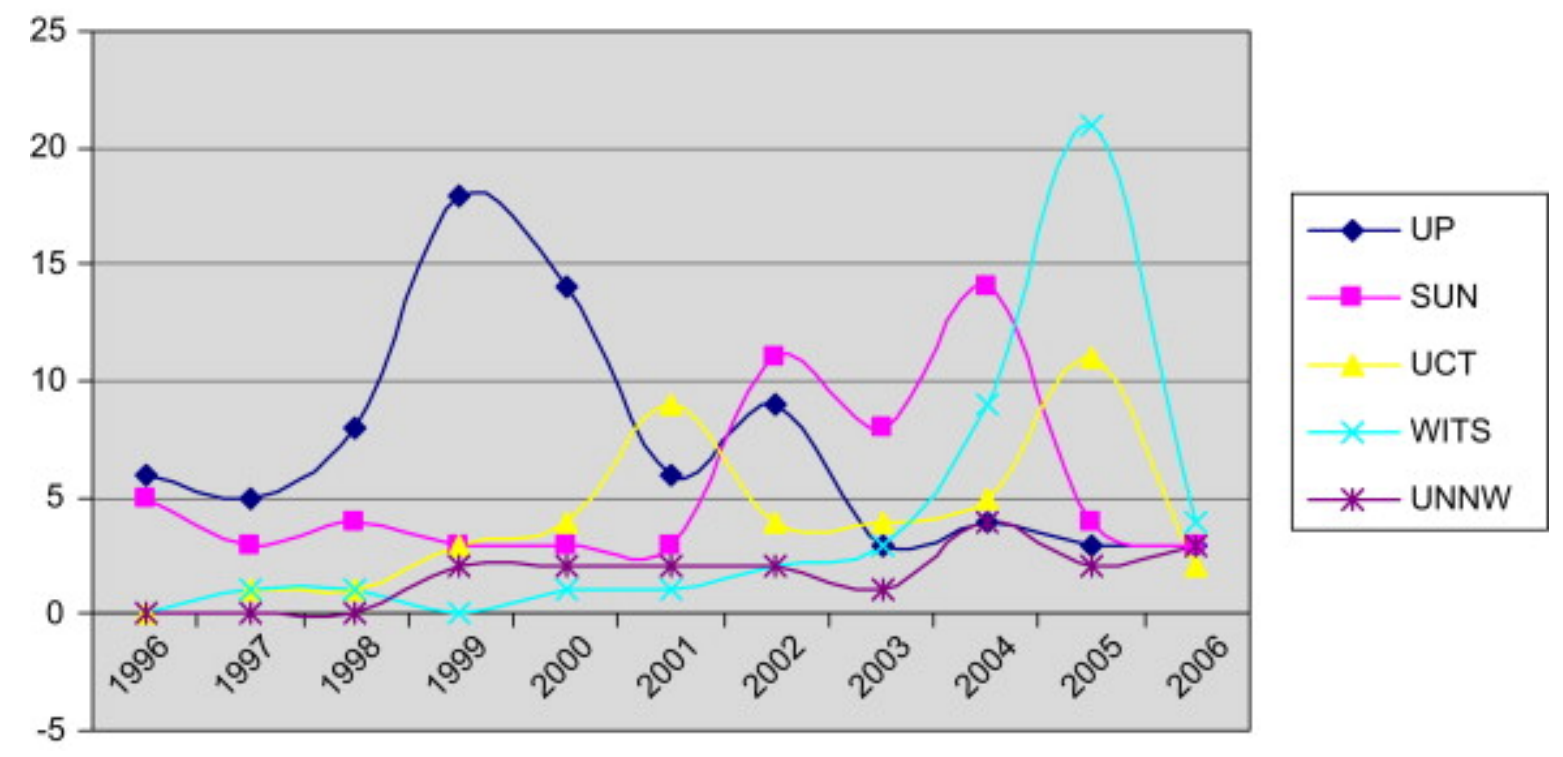


Fig. 1. Patent application to CIPRO by South African University from 1996 to 2006. Table 1 shows the \% of patent applications by the five universities for the last 10 years. The University of Pretoria has the most applications followed by Stellenbosch University. The University of Cape Town and the University of Witwatersrand, Johannesburg display similar performance and are followed by the university of the North West.

Table 1.

Distribution of (\%) patent application by five South African universities (1996-2006)

\begin{tabular}{|l|l|l|l|l|l|}
\hline University & UP & SUN & UCT & WITS & UNNW \\
\hline \% of patent applications & 32 & 25 & 18 & 18 & 7 \\
\hline Total number of applications & 79 & 61 & 44 & 43 & 18 \\
\hline
\end{tabular}

Table 2 shows that the University of Pretoria has 79 patent applications. Faculties and names of inventors of six patents applications (termed others) were not obtained. Cvs of nine inventors were not obtained. For the remaining 64 patent applications 63 inventors had previous industry work experience. Only one inventor without previous industry work experience had an application. The Department of Chemical Engineering has 15 applications and is followed by the Department of Electrical, Electronic and Computer Engineering which has 14 applications. The Departments of Metallurgical and Mechanical Engineering each have seven applications. They are followed by the Departments of Microbiology which has five applications, and Pharmacology which has four. The Departments of Veterinary Science, Educational Psychology and Biochemistry have three applications each and they are followed by the Departments of Physics and Radiation Oncology which have two each. The Department of Chemistry comes last with only one application. 
Table 2.

Distribution of patent application by department and inventor's industry work experience, UP

\begin{tabular}{|c|c|c|c|c|}
\hline \multirow[t]{2}{*}{ Department } & \multirow[t]{2}{*}{ Applications } & \multicolumn{2}{|c|}{$\begin{array}{l}\text { Inventor worked for } \\
\text { industry }\end{array}$} & \multirow[t]{2}{*}{$\begin{array}{l}\text { No } \\
\text { responses }\end{array}$} \\
\hline & & Yes $=1$ & $\mathbf{N o}=\mathbf{0}$ & \\
\hline Biochemistry & 3 & 2 & 0 & 1 \\
\hline Botany & 4 & 4 & 0 & 0 \\
\hline Chemical Engineering & 15 & 13 & - & 2 \\
\hline Chemistry & 1 & 1 & 0 & 0 \\
\hline Civil Engineering & 2 & 2 & 0 & 0 \\
\hline EEC ${ }^{\underline{a}}$ Engineering & 14 & 14 & 0 & 0 \\
\hline Educational Psychology & 3 & 2 & - & 0 \\
\hline Entomology & 1 & 1 & 0 & 0 \\
\hline Mechanical Engineering & 7 & 7 & 0 & 0 \\
\hline $\begin{array}{l}\text { Metallurgical } \\
\text { Engineering }\end{array}$ & 7 & 3 & - & 4 \\
\hline Microbiology & 5 & 4 & 0 & 1 \\
\hline Pharmacology & 4 & 4 & 0 & 0 \\
\hline Physics & 2 & 2 & 0 & 0 \\
\hline Radiation Oncology & 2 & 2 & 0 & 0 \\
\hline Veterinary Science & 3 & 3 & 0 & 0 \\
\hline Others & 6 & & & \\
\hline Total & 79 & 64 & 0 & 8 \\
\hline
\end{tabular}

${ }^{\mathrm{a}}$ (EEC Engineering) denotes Electrical, Electronic and Computer Engineering.

Table 3 shows that the University of Cape Town has 44 patent applications. Faculty and name of an inventor for one patent application (others) were not obtained. Cvs of five inventors were not obtainable. For the remaining 38 applications, 37 inventors had previous industry work experience. Only one inventor without industry work experience 
had an application. The Department of Molecular and Cell Biology displays the highest performance with 13 applications and is followed by the Department of Chemical Engineering which has six applications. The Department of Biomedical Engineering (Biomechanical Engineering) has five applications and Pharmacy, four. The Departments of Chemical Pathology and Internal Medicine have three applications each. The Department of Physics has two applications. The Departments of Biochemistry, Civil Engineering and Electrical Engineering each have one application.

Table 3.

Distribution of patent applications by department and inventor's industry work experience, UCT

\begin{tabular}{|c|c|c|c|c|}
\hline \multirow[t]{2}{*}{ Department } & \multirow[t]{2}{*}{ Applications } & \multicolumn{2}{|c|}{$\begin{array}{l}\text { Inventor worked for } \\
\text { industry }\end{array}$} & \multirow[t]{2}{*}{$\begin{array}{l}\text { No } \\
\text { responses }\end{array}$} \\
\hline & & Yes $=1$ & No $=0$ & \\
\hline Biochemistry & 1 & 1 & 0 & 0 \\
\hline Biomedical Engineering & 5 & 5 & 0 & 0 \\
\hline Chemical Engineering & 6 & 4 & - & 2 \\
\hline Chemical Pathology & 3 & 3 & 0 & 0 \\
\hline Chemistry & 4 & 4 & 0 & 0 \\
\hline Civil Engineering & 1 & 1 & 0 & 0 \\
\hline Electrical Engineering & 1 & 1 & 0 & 0 \\
\hline Internal Medicine & 3 & 3 & 0 & 0 \\
\hline $\begin{array}{l}\text { Molecular and Cell } \\
\text { Biology }\end{array}$ & 13 & 11 & - & 2 \\
\hline Pharmacy & 4 & 4 & 0 & 1 \\
\hline Physics & 2 & - & 1 & 1 \\
\hline Others & 1 & & & \\
\hline Total & 44 & 37 & 1 & 6 \\
\hline
\end{tabular}


Table 4 shows that Stellenbosch University has 61 patent applications. Faculties and names of inventors of seven patents applications (termed others) were not obtained. Cvs of nine inventors were not obtained. For the remaining 45 patent applications all inventors with previous industry work experience had patent applications. No inventors without previous industry work experience had a patent application.

Table 4.

Distribution of patent application by department and inventor's industry work experience, SUN

\begin{tabular}{|l|l|l|l|l|}
\hline Department & Applications & $\begin{array}{l}\text { Inventor worked for } \\
\text { industry }\end{array}$ & $\begin{array}{l}\text { No } \\
\text { responses }\end{array}$ \\
\hline & & Yes=1 & No=0 & \\
\hline Biochemistry & 4 & 4 & 0 & 0 \\
\hline Chemical Engineering & 2 & 2 & 0 & 0 \\
\hline Chemistry & 11 & 11 & 0 & 0 \\
\hline Civil Engineering & 1 & 1 & 0 & 0 \\
\hline EE⿱ Engineering & 12 & 9 & - & 3 \\
\hline $\begin{array}{l}\text { Forestry and Wood } \\
\text { Science }\end{array}$ & 3 & - & - & 3 \\
\hline Mechanical Engineering & 3 & 1 & - & 2 \\
\hline Medical Virology & 2 & 2 & 0 & 0 \\
\hline Microbiology & 16 & 15 & - & 1 \\
\hline Others & 7 & - & - & - \\
\hline Total & 61 & 45 & 0 & 9 \\
\hline
\end{tabular}

${ }^{\mathrm{a}}$ (EE Engineering) denotes Electrical and Electronic Engineering.

The Department of Microbiology shows the highest inventive capacity with six applications and is followed by the Department of Electrical and Electronic Engineering, which have 12 applications. The Department of Chemistry has eleven applications and 
Biochemistry four. The Departments of Forestry, Wood Science and Mechanical Engineering have three applications each. The Departments of Chemical engineering and Medical Virology each have two applications. The Department of Civil Engineering has only one application.

Table 5 shows that the University of the Witwatersrand has 43 patents applications.

Faculties and names of inventors of six patent applications (termed others) were not obtained. Cvs of eight inventors were not obtained. For the remaining 29 patent applications 28 inventors had previous industry work experience. Only one inventor with no previous industry work experience had an application.

Table 5.

Distribution of patent application by department and inventor's industry work experience, WITS

\begin{tabular}{|l|l|l|l|l|}
\hline Department & Applications & \multicolumn{2}{|l|}{$\begin{array}{l}\text { Inventor worked for } \\
\text { industry }\end{array}$} & $\begin{array}{l}\text { No } \\
\text { responses }\end{array}$ \\
\hline & & Yes=1 & No=0 & \\
\hline Chemical Engineering & 5 & 5 & 0 & 0 \\
\hline Chemistry & 3 & 3 & - & 1 \\
\hline Civil Engineering & 2 & 2 & 0 & 0 \\
\hline EI - Engineering & 2 & 2 & 0 & 0 \\
\hline Mechanical Engineering & 3 & - & - & 3 \\
\hline Pathology & 1 & 1 & 0 & 0 \\
\hline Medical Genetics & 2 & 2 & 0 & 0 \\
\hline $\begin{array}{l}\text { Molecular and Cell } \\
\text { Biology }\end{array}$ & 4 & 1 & 1 & 2 \\
\hline Pharmacy & 3 & 3 & 0 & 0 \\
\hline Physics & 11 & 10 & - & 1 \\
\hline Physiology & 1 & - & - & 1 \\
\hline Others & 6 & - & - & - \\
\hline Total & 43 & 29 & 1 & 8 \\
\hline
\end{tabular}


a (EI Engineering) denotes Electrical and Information Engineering.

The Department of Physics displays the highest inventive capacity with eleven patent applications and is followed by the Department of Chemical Engineering which has five. The Department of Molecular and cell Biology has four applications, Chemistry, Pharmacy and mechanical Engineering each have three applications. The Departments of Civil Engineering, Medical genetics and Electrical and Information engineering each have two patent applications. The Departments of Orthopaedics and Physiology have one application each.

Table 6 shows that the University of the North West has 18 applications. Faculties and name of inventors of two patents (termed others) were not obtained. Cvs of three inventors were not obtained. Inventors of the three remaining applications had previous industry work experience. No inventor without work experience had an application. The Department of Electrical Engineering has the highest inventive capacity with seven patent applications and is followed by the Department of Chemical Engineering, which has five applications. The Department of Chemistry has two application and is followed by the Departments of Civil Engineering and Nutrition.

Table 6.

Distribution of patent application by department and inventor's industry work experience, UNNW

\begin{tabular}{|l|l|l|l|l|}
\hline Department & Applications & \multicolumn{2}{|l|}{ Inventor worked for industry } & No responses \\
\hline & & Yes=1 & No=0 & \\
\hline Chemical Engineering & 5 & 3 & - & 2 \\
\hline Chemistry & 2 & 1 & - & 1 \\
\hline Civil Engineering & 1 & 1 & 0 & 0 \\
\hline Electrical Engineering & 7 & 7 & 0 & 0 \\
\hline Nutrition & 1 & 1 & 0 & 0 \\
\hline Others & 2 & - & - & - \\
\hline Total & 18 & 13 & 0 & 3 \\
\hline
\end{tabular}


Table 7 compares the performances of faculties of Science, Engineering and Health of the five universities under investigation on the inventive capacity. In the faculties of Science, Stellenbosch University has the highest inventive capacity with 31 patents applications and is followed by the University of Cape Town, which has 20. The University of the Witwatersrand has eighteen applications and The University of Pretoria has 16. The University of the North West has three applications. The University of Pretoria leads in the faculties of Engineering with 45 applications and is followed by Stellenbosch University, which has 18 applications. The University of Cape Town has 13 applications and the University of the North West has 13. The University of the Witwatersrand has 12 applications. The faculties of Health are dominated by the University of Cape Town which has 11 applications. The University of the Witwatersrand has seven applications, the University of Pretoria six, Stellenbosch University two and the University of the North West one.

Table 7.

Distribution of patent applications by faculties (Engineering, Science and Health), by institution

\begin{tabular}{|l|l|l|l|l|l|}
\hline Faculty & \multicolumn{5}{|l|}{ Patent applications } \\
\hline & SUN & UP & UCT & WITS & UNNW \\
\hline Engineering & 18 & 45 & 13 & 12 & 13 \\
\hline Science & 31 & 16 & 20 & 18 & 3 \\
\hline Health & 2 & 6 & 11 & 7 & 1 \\
\hline Total & 51 & 67 & 44 & 37 & 17 \\
\hline
\end{tabular}

Table 8 shows the performance of the control group in patent applications. It can be seen that our findings support strongly the hypothesis that previous working experience in the private sector affects inventive activity. 
Table 8.

Control group

\begin{tabular}{|l|l|l|l|}
\hline \multirow{2}{*}{ Number of professors } & \multicolumn{2}{|l|}{ Inventor worked for industry } & \multirow{2}{*}{ Applications } \\
\hline & Yes=1 & No=0 & \\
\hline 20 & 0 & 20 & 0 \\
\hline 10 & 7 & 3 & 7 \\
\hline
\end{tabular}

In this article we first investigate the inventive activity of five South African Universities as it is manifested in patent applications to the South African patent office. CIPRO provides a more detailed picture of South African inventive activities than USPTO. The University of Pretoria has the highest overall patent applications and is followed by the Stellenbosch University, the University of Cape Town, the University of the Witwatersrand and the University of the North West.

The performance of the five universities has been compared based on their inventiveness in the faculties of Science, Engineering and Health. The University of Pretoria has the highest inventive activities with 67 patent applications and is followed by Stellenbosch University, which has 51. The University of Cape Town has 44 applications, the University of the Witwatersrand 37 and the University of the North West 17. The faculty of Science of the Stellenbosch University appears to have the highest inventive capacity with 31 patents amongst the institutions considered. Two departments including Microbiology with 16 applications and Chemistry with 11 appear to be the major contributors to the inventive capacity of this faculty. The University of Cape Town follows Stellenbosch University in Science with 20 applications the most of which being made by the Departments of Molecular and Cell Biology which has 13 applications and Chemistry which has four. The University of the Witwatersrand comes after the University of Cape Town with 18 applications. The major part of the University of the Witwatersrand applications are from the Departments of Physics which has 11 applications and Molecular and Cell Biology which has four. The University of Pretoria has 16 applications mainly from Microbiology with five and Botany four and 
Biochemistry with three. Lastly the University of the North West has two applications, all from Chemistry.

The University of Pretoria leads in the faculties of Engineering with 45 applications. The major part of these applications is from the Departments of Chemical Engineering, which has 15 and Electrical Engineering, which has 14. The Departments of Mechanical Engineering and Metallurgical Engineering each have seven applications. Stellenbosch University follows the University of Pretoria with 18 applications most of these coming from the Department of Electrical and Electronic Engineering which has 12 and Mechanical Engineering which has three. The University of Cape Town comes after Stellenbosch University with thirteen applications. The major part of these applications is from the Department of Chemical Engineering, which has six applications and Biomedical Engineering (Biomechanical Engineering), which has five. The University of the North West has thirteen applications, the major part of them coming from the Department of Electrical Engineering which has seven and Chemical Engineering which has five applications. The University of the Witwatersrand has 12 applications, the major part of them coming from the Department of Chemical Engineering which has five applications and Mechanical Engineering three.

The faculties of Health are dominated by the University of Cape Town with 11 applications, the major part of them coming from the Department of Pharmacy which has four and Chemical pathology three. The University of the Witwatersrand follows the University of Cape Town which has seven applications, mostly from the Department of Pharmacy which has two and Genetics which has two. The University of Pretoria comes after the University of the Witwatersrand with six mainly from the Department of Pharmacology which has four applications and Radiation Oncology which has two. Stellenbosch University has two applications from the Department of Medical Virology and the University of the North West has one application. 
The dramatic increase in inventive activities at WITS in 2005 and the decrease of such activities at UP from 2002 as well as the big differences in inventive activities amongst institutions and departments are subject of further research.

It is worth mentioning that the analysis of inventive activities of the five South African institutions considered in this study at the USPTO (US Patent and Trademark Office) gives a low coverage of patenting activities. UP, for example, has only five patents granted; WITS zero, UNNW one, UCT two and SUN one. This suggests that CIPRO provides a more detailed picture of South African inventive activities compared to that of USPTO. Considering patent application at national level can provide a broader picture of innovative or inventive activities in countries.

The overall performances of South Africa however over the period of 10 years which is less than 300 patents, appear to be far below that of other countries. Italy, for example, had about 1475 patent applications (from universities) from 1978 to 1999 (Balconi et al., 2004). Taiwan, 1009 from 1997 to 2001 (Chang et al., 2006). South Africa's higher education authorities and the universities administrations should consider the enactment of appropriate incentives in order to improve the inventive outputs of the country's universities. Building a strong entrepreneurial capacity (e.g. employing CEO, former CEO or people with business mindset in faculties, departments and technology transfer offices, raising the awareness of the market needs and dynamics, promoting business and managerial cultures and skills amongst researchers through workshops, etc.), strengthening the management capabilities of technology transfer offices, promoting effective links with the private sector, setting up research joint ventures, collaborations with technology incubators, adopting royalty and equity policies that stimulate researchers to invent and innovate are some examples in this direction.

In the second leg of the investigation we find that industrial work experience actually enhances inventive capacity (as measured by patent applications). Inventive capacity of professors endowed with industry experience typically differs from that whose entire career is spent in academia. Prior industry working experience of scientists working at 
university appears to be an effective mechanism (through which knowledge is transferred from industry to university and) that increases the university's inventive activities. The evidence displayed by the test of the control group seems in line with the general observation on the strong association between industry work experience and patent applications. Our findings support strongly the hypothesis that previous working experience in the private sector affects positively inventive activity.

\section{Conclusion and recommendations}

The analysis of inventive activities of the five South African institutions considered in this study at domestic level reveals that CIPRO provides a more detailed picture of South African inventive activities than foreign patent offices such as USPTO. Considering patent application at national level can provide a broader picture of innovative or inventive activities in foreign countries. However the equivalence of local and international patents should first be established. A related issue is the question of why South African academics patent locally and not abroad. Is it an issue of costs, market considerations or they find it easier to apply in a patent office which grants patents using different criteria? In general, though it can be argued that indicators based on local patent offices can provide valuable information that is not always available through analyses of patents granted by foreign patent offices.

The overall performances of South Africa over the period of 10 years, appear to be far below that of other countries. South Africa's relevant policy authorities and the 'universities' administrations should consider the enactment of appropriate incentives in order to improve the inventive outputs of the country's universities. Employing researchers with prior industry or business experience, building a strong entrepreneurial capacity, strengthening the management capabilities of technology transfer offices, promoting effective links with the private sector, setting up research joint ventures, collaborations with technology incubators, adopting royalty and equity policies that stimulate researchers to invent and innovate are some examples in this direction. 
The dramatic increase in inventive activities at WITS in 2005 and the decrease of such activities at UP from 2002 as well as the big differences in inventive activities amongst institutions and departments are subject to further research.

In the second leg of the investigation we find that prior industry working experience of scientists working at universities appear to be an effective mechanism that increases the universities' inventive activities. Invention is certainly a complex process that heavily requires specific skills from various areas of industry (production, development and applied research, etc.) which have to be combined with other resources to generate novel and useful product or process. Our findings are similar to those of Dietz and Bozeman (2005) supporting the view that the intersectoral job change by researchers from industries to universities is associated with the spillover of industry-specific human capital (learned and accumulated over time through working experience) to universities. We also support the view that the spillover of the industry-specific knowledge is an effective mechanism in supporting new knowledge generation capacity needed in invention. We suggest that the foregoing views are universal. They hold, for example, even in South Africa where the patenting culture and the supporting mechanisms for innovation available in the developed economies are not present. While it will be important to verify this linkage between prior industrial working experience and academic inventiveness in other countries, we suggest that this is an international phenomenon and that universities wishing to improve their entrepreneurial character should aim to employ academics with industry prior experience.

\section{References}

Abraham and Moitra, 2001 B.P. Abraham and S.D. Moitra, Innovation assessment through patent analysis, Research Policy 21 (2001), pp. 245-252.

Archibugi and Coco, 2005 D. Archibugi and A. Coco, Measuring technological capabilities at the country level: a survey and a menu for choice, Research Policy 34 (2005), pp. 175-194. 
Autio et al., 1996 E. Autio, A. Hameri and M. Nordberg, A framework of motivations for industry-big science collaboration: a case study, Journal of Engineering and Technology Management 13 (1996), pp. 301-314.

Balconi et al., 2004 M. Balconi, S. Breschi and F. Lissoni, Networks of inventors and the role of academia: an exploration of Italian patent data, Research Policy 33 (2004), pp. $127-145$.

Bozeman and Corley, 2004 B. Bozeman and E. Corley, Scientists' collaboration strategies: implications for scientific and technical human capital, Research Policy 33 (2004), pp. 599-616.

Bozeman and Mangematin, 2004 B. Bozeman and V. Mangematin, Editor's introduction: building and deploying scientific and technical human capital, Research Policy 33 (2004), pp. 565-568.

Bray and Lee, 2000 M. Bray and J.N. Lee, University revenues from technology transfer: licensing fees vs. equity positions, Journal of Business Venturing 15 (2000), pp. 385392.

Chang et al., 2006 Y. Chang, M. Chen, M. Hua and P.Y. Yang, Managing academic innovation in Taiwan: towards a "scientific-economic" framework, Technological Forecasting and Social Change 73 (2006), pp. 199-213.

Chapple et al., 2005 W. Chapple, A. Lockett, D. Siegel and M. Wright, Assessing the relative performance of UK university technology transfer offices: parametric and nonparametric evidence, Research Policy 34 (2005), pp. 369-384.

Coombs et al., 1996 R. Coombs, P. Narandren and A. Richards, A literature-based innovation output indicator, Research Policy 25 (1996), pp. 403-413. 
Cummings and Teng, 2003 J.L. Cummings and B. Teng, Transferring R\&D knowledge: the key factors affecting knowledge transfer success, Journal of Engineering and Technology Management 20 (2003), pp. 39-68.

Daghfous, 2004 A. Daghfous, An empirical investigation of the roles of prior knowledge and learning activities in technology transfer, Technovation 24 (2004), pp. 939-953.

Dietz and Bozeman, 2005 J.S. Dietz and B. Bozeman, Academic careers, patents, and productivity: industry experience as scientific and technical human capital, Research Policy 34 (2005), pp. 349-367.

Etzkowitz, 1998 H. Etzkowitz, The norms of entrepreneurial science: cognitive effects of the new university-industry linkages, Research Policy 27 (1998), pp. 823-833.

Faulkner, 1998 W. Faulkner, Knowledge flow in innovation. In: W. Williams, W. Faulker and J. Fleck, Editors, Exploring Expertise: Issues and Perspectives, MacMillan, London (1998), pp. 173-196.

Gans and Hayes, 2005 Gans, J., Hayes, R., 2005. Assessing Australia's innovative capacity (2005) update, 22nd December 2005. Report Melbourne Business School and Intellectual Property Research Institute of Australia, University of Melburne.

Grupp and Mogee, 2004 H. Grupp and M.E. Mogee, Indicators for national science and technology public policy: how robust are composite indicators?, Research Policy 33 (2004), pp. 1373-1384.

Hameri, 1996 A.-P. Hameri, Technology transfer between basic research and industry, Technovation 16 (2) (1996), pp. 51-57. 
Liu and Jiang, 2001 H. Liu and Y. Jiang, Technology transfer from higher education institutions to industry in China: nature and implications, Technovation 21 (2001), pp. 175-188.

Madanmohan et al., 2004 T.R. Madanmohan, U. Kumar and V. Kumar, Import-led technological capability: a comparative analysis of Indian and Indonesian manufacturing firms, Technovation 24 (2004), pp. 979-993.

McAdam, 2004 R. McAdam, Knowledge creation and idea generation: a critical quality perspective, Technovation 24 (2004), pp. 697-705.

Miyata, 2000 Y. Miyata, An empirical analysis of innovative activity of universities in the United States, Technovation 20 (2000), pp. 413-425.

Mohan and Rao, 2005 S.R. Mohan and A.R. Rao, Strategy for technology development in public R\&D institutes by partering with the industry, Technovation 25 (2005), pp. $1484-1491$.

Motohashi, 2005 K. Motohashi, University-industry collaborations in Japan: the role of new technology-based firms in transforming the National Innovation System, Research Policy 34 (2005), pp. 583-594.

Murray, 2004 F. Murray, The role of academic inventors in entrepreneurial firms: sharing laboratory life, Research Policy 33 (2004), pp. 643-659.

Ndonzuau et al., 2002 F.N. Ndonzuau, F. Pirnay and B. Surlemont, A stage model of academic spin-off creation, Technovation 22 (2002), pp. 281-289.

Nieto and Quevedo, 2005 M. Nieto and P. Quevedo, Absorptive capacity, technological opportunity, knowledge spillovers, and innovative efforts, Technovation 25 (2005), pp. 1141-1157. 
Numprasertchai and Igel, 2005 S. Numprasertchai and B. Igel, Managing knowledge through collaboration: multiple case studies of managing research in university laboratories in Thailand, Technovation 25 (2005), pp. 1173-1182.

Pouris, 2005 A. Pouris, Technological performance judged by American patents awarded to South African inventors, South African Journal of Science 101 (2005), pp. 221-224.

Pouris, 2006 Pouris, A., 2006. Technology transfer and diffusion: capacity and potential in South-Africa's public higher education sector. Research report for Higher Education South Africa-HESA, June 2006.

Rogers et al., 2001 E.M. Rogers, S. Takegami and J. Yin, Lessons learned about technology transfer, Technovation 21 (2001), pp. 253-261.

Verspagen and Duysters, 2004 B. Verspagen and G. Duysters, The small world of strategic technology alliances, Technovation 24 (2004), pp. 563-571.

Veugelers and Cassiman, 2005 R. Veugelers and B. Cassiman, R\&D cooperation between firms and universities. Some empirical evidence from Belgian manufacturing, International Journal of Industrial Organization 23 (2005), pp. 355-379.

Watanabe et al., 2001 C. Watanabe, Y.S. Tsuji and C. Griffy-Brown, Patent statistics: deciphering a "real” versus a "pseudo" proxy of innovation, Technovation 21 (2001), pp. 783-790.

Zellner, 2003 C. Zellner, The economic effects of basic research: evidence for embodied knowledge transfer via scientists' migration, Research Policy 32 (2003), pp. 1881-1895. 
Corresponding author. Tel.: +27 124203843 .

\section{Vitae}

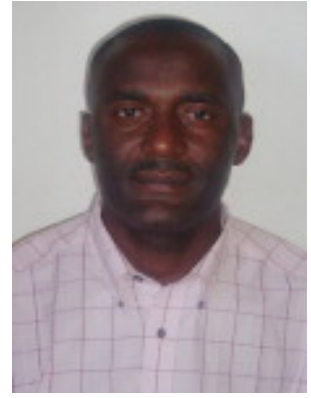

Louis M Lubango worked as a researcher and consultant in private sector and in universities in areas of chemistry and chemical technologies in South Africa. He was particularly involved in prototype evaluation and development, new products and process development and dissemination to different countries, in the fields of analytical equipments, petrochemicals, ceramics, catalysts, energy generation, pollution control, etc. He received an M.Sc. in chemical processes, a Certificate in Reactors Synthesis/Engineering from the University of the Witwatersrand and a B.Sc. Honours in Industrial Chemtry from the UB. He also worked as a researcher in philosophy of science before joining the Institute of Technological Innovation of the University of Pretoria where he is completing his Ph.D. in issues of technology and innovation management and policy.

Professor Pouris is Director of the Institute for Technological Innovation of the University of Pretoria, South Africa. He is specializes in science, technology and innovation policy development

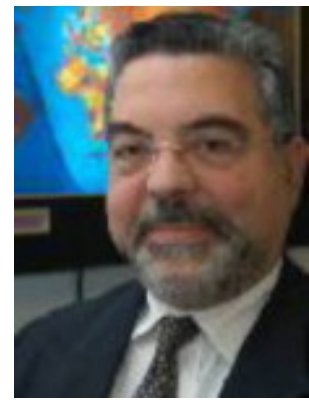
studies, including assessments and priority related exercises. He acts as consultant for a number of government departments in South Africa (i.e. Department of Science and Technology, Department of Trade and Industry, Department of Public Enterprises) and various international organizations (e.g. UNESCO, NEPAD and others). His educational background includes Engineering from the university of Thessaloniki Greece, Economics from the University of Surrey Guildford and Ph.D. from the University of Cape Town, South Africa. He has published a large number of articles in internationally refereed journals. 